\title{
The inhibition of tyrosinase by pyridinones
}

\section{Robert C. HIDER* and Konrad LERCH†}

*Department of Pharmacy, King's College London (Chelsea Campus), Manresa Road, London SW3 6LX, U.K., and †Biochemisches Institut, Universität Zürich-Irchel, Winterthurerstrasse 190, CH-8057 Zürich, Switzerland

3-Hydroxypyridine-4-ones have potential as orally active chelators of iron(III) and therefore may find application in the treatment of thalassaemia. An undesirable feature of these molecules is that they inhibit tyrosinase. We have established that alkyl substitution at position 2 in the aromatic ring minimizes interaction with tyrosinase and does so without appreciably influencing the affinity for iron(III).

\section{INTRODUCTION}

Tyrosinase is a copper-containing mono-oxygenase (EC 1.14.18.1) that catalyses the ortho-hydroxylation of monophenols and the oxidation of $o$-diphenols to $o$ quinones (Mason, 1965). The enzyme is involved in the conversion of tyrosine into dopa (3,4-dihydroxyphenylalanine) and in the synthesis of melanin (Lerch, 1981). Tyrosinase interacts with a range of copper-chelating compounds, including aminophenols (Toussaint \& Lerch, 1987), aromatic carboxylic acids (Wilcox et al., 1985 ) and arylamines (Toussaint \& Lerch, 1987). Tyrosinase is also inhibited by L-mimosine (Ia), a naturally occurring pyridinone (Hashiguchi \& Takahashi, 1977), and as this compound is a powerful chelator of copper(II) (Stünzi et al., 1979, 1980) it probably also binds to the copper atoms situated at the active site of tyrosinase. However, in contrast with catechols, the corresponding quinone (Scheme 1) is unstable, and therefore when mimosine binds to the active-site copper ion it is not transformed into a quinone and consequently remains bound.

Mimosine is a 3-hydroxypyridin-4-one derivative and

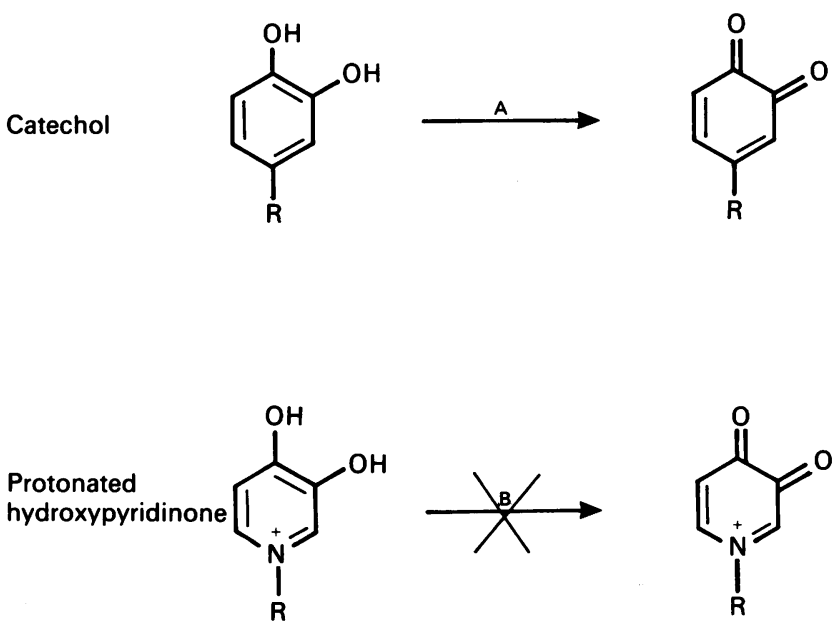

Scheme 1. Tyrosinase-catalysed catechol oxidations

Catechols are converted into $o$-quinones by tyrosinase (route A), but in contrast hydroxypyridinones are not converted into quinone-containing structures (route B).

Table 1. Structures of the chelating inhibitory molecules: (I) 3-hydroxypyridine-4-ones, (II) 3-hydroxypyridine-2-ones and (III) 3hydroxypyran-4-ones<smiles>[R]c1c(O)c(=O)ccn1[R]</smiles>

(1)<smiles>[R]n1cccc(O)c1=O</smiles>

(II)<smiles>[R]c1cc(=O)c(O)c([R])o1</smiles>

(III)

\begin{tabular}{lll}
\hline (Ia) & $\mathbf{R}=\mathrm{CH}_{2} \mathrm{CH}\left(\mathrm{NH}_{2}\right) \mathrm{CO}_{2} \mathrm{H}$, & $\mathbf{R}^{\prime}=\mathrm{H}$ \\
(Ib) & $\mathbf{R}=\mathrm{CH}_{2} \mathrm{CH}_{2} \mathrm{NH}_{2}$, & $\mathbf{R}^{\prime}=\mathrm{H}$ \\
(Ic) & $\mathrm{R}=\mathrm{CH}_{2} \mathrm{CH}_{3}$, & $\mathbf{R}^{\prime}=\mathrm{H}$ \\
(Id) & $\mathbf{R}=\mathrm{CH}_{3}$, & $\mathbf{R}^{\prime}=\mathrm{CH}_{3}$ \\
(Ie) & $\mathrm{R}=\mathrm{CH}_{2} \mathrm{CH}_{3}$, & $\mathbf{R}^{\prime}=\mathrm{CH}_{3}$ \\
(If) & $\mathbf{R}=\mathrm{CH}_{2} \mathrm{CH}_{2} \mathrm{CH}_{3}$, & $\mathbf{R}^{\prime}=\mathrm{CH}_{3}$ \\
(Ig) & $\mathbf{R}=\mathrm{CH}_{2} \mathrm{CH}_{2} \mathrm{CO}_{2} \mathrm{H}$, & $\mathbf{R}^{\prime}=\mathrm{CH}_{3}$ \\
(Ih) & $\mathbf{R}=\mathrm{CH}_{2} \mathrm{CH}_{2} \mathrm{OH}$, & $\mathbf{R H}^{\prime}=\mathrm{CH}_{3}$ \\
(Ii) & $\mathbf{R}=\mathrm{CH}_{2} \mathrm{CH}_{2} \mathrm{NH}_{2}$ & $\mathbf{R}^{\prime}=\mathrm{CH}_{3}$ \\
(Ij) & $\mathbf{R}=\mathrm{CH}_{2} \mathrm{CH}_{2} \mathrm{OCH}_{3}$, & $\mathbf{R}^{\prime}=\mathrm{CH}_{3}$ \\
(Ik) & $\mathbf{R}=\mathrm{CH}_{3}$ & $\mathbf{R}^{\prime}=\mathrm{CH}_{2} \mathrm{CH}_{3}$
\end{tabular}

* To whom correspondence should be addressed. 
Table 2. Inhibition of tyrosinase by iron chelators

Kinetic constants were obtained from Dixon (1953) plots. Assays were carried out with $3 \mathrm{ml}$ of air-saturated L-dopa as substrate (4 mM) dissolved in $0.1 \mathrm{M}$-potassium phosphate buffer, $\mathrm{pH}$ 6.0. The rate of product formation was monitored spectrophotometrically at $30^{\circ} \mathrm{C}$ at $475 \mathrm{~nm}$ (Lerch, 1987).

\begin{tabular}{|c|c|c|c|}
\hline Substrate & $K_{\mathrm{i}}(\mathrm{mM})$ & Substrate & $K_{\mathrm{i}}(\mathrm{mM})$ \\
\hline $\begin{array}{l}\text { 3-Hydroxypyridin- } \\
\text { 4-ones }\end{array}$ & \multicolumn{3}{|c|}{$\begin{array}{l}\text { 3-Hydroxypyridin- } \\
\text { 2-ones }\end{array}$} \\
\hline (Ia) & 0.045 & (IIa) & 0.022 \\
\hline (Ib) & 0.014 & (IIb) & 1.5 \\
\hline (Ic) & 0.004 & & \\
\hline (Id) & 5.6 & & \\
\hline (Ie) & 2.2 & 3-Hydroxypyran- & \\
\hline (If) & 2.6 & 4-ones & \\
\hline (Ig) & 7.6 & (IIIa) & 17.0 \\
\hline (Ih) & 3.2 & (IIIb) & 0.008 \\
\hline (Ii) & 0.8 & & \\
\hline (Ij) & 5.6 & & \\
\hline (Ik) & 6.2 & & \\
\hline
\end{tabular}

is therefore closely related to a group of pyridinones that has been developed as orally active iron chelators (Hider et al., 1982; Gyparaki et al., 1987; Porter et al., 1988). High daily doses of pyridinone will be required for the treatment of patients suffering from iron overload, and consequently it is important to establish whether the selected ion chelators inhibit tyrosinase. Three classes of molecule have been tested, namely 3-hydroxypyridin-4ones (I), 3-hydroxypyridin-2-ones (II) and 3-hydroxypyran-4-ones (III) (Table 1), with Neurospora crassa tyrosinase (Lerch, 1987).

\section{EXPERIMENTAL AND RESULTS}

All the pyridine-4-ones tested were found to inhibit tyrosinase, but with a wide range of $K_{\mathrm{i}}$ values (Table 2). Significantly the ligands lacking an alkyl substituent on the aromatic ring [(Ia), (Ib) and (Ic)] are highly potent inhibitors. In contrast, those ligands possessing a methyl or ethyl substituent ortho to the chelating oxygen atoms [(Id)-(Ik)] were much weaker inhibitors (at least 100-fold decrease in $K_{\mathrm{f}}$ value). Similar findings are obtained with the pyridine-2-ones, where the presence of the methyl function has a dramatic influence on the $K_{1}$ value (Table 2). Again pyranones show the same trend, maltol (IIIa) being a weak inhibitor, whereas kojic acid (IIIb) is quite potent (Table 2). Maltol possesses a methyl function ortho with respect to the chelating oxygen atoms whereas kojic acid does not.

The presence of $o$-alkyl functions does not influence the affinity constant for the interaction between pyridinones and either iron(III) or copper(II) (P. D. Taylor \& R. C. Hider, unpublished work). Therefore the presence of these groups must create steric congestion, whereby the ligand is unable to approach the copper atom at the active site of tyrosinase in a bidentate fashion. A similar effect of steric hindrance has been observed previously for different ortho-substituted benzoic acids (Wilcox et al., 1985).

\section{DISCUSSION}

This simple observation is of critical importance for clinical chelator design. The maximum blood concentration after a normal oral dose is unlikely to exceed $100 \mu \mathrm{M}$, a concentration that is at least 20 times lower than the $K_{\mathrm{i}}$ value for alkyl-substituted pyridinones. We consider it unlikely that the pyridinones"(Id), (Ie), (Ij) and (Ik) will generate toxic side effects by virtue of tyrosinase inhibition.

K.L. acknowledges the Swiss National Science Foundation (Grant no. 3.236-0.85); R.C.H. acknowledges financial support from the British Technology Group.

\section{REFERENCES}

Dixon, M. (1953) Biochem. J. 55, 170-177

Gyparaki, M., Porter, J. B., Huehns, E. R. \& Hider, R. C. (1987) Acta Haematol. 78, 217-223

Hashiguchi, H. \& Takahashi, H. (1977) Mol. Pharmacol. 13, 362-367

Hider, R. C., Kontoghiorghes, G. \& Silver, J. (1982) U.K. Patent 2118176

Lerch, K. (1981) Met. Ions Biol. Systems 13, 143-186

Lerch, K. (1987) Methods Enzymol. 142, 165-169

Mason, H. S. (1965) Annu. Rev. Biochem. 34, 595-634

Porter, J. B., Gyparaki, M., Burke, L. C., Huehns, E. R., Sarpong, P., Saez, V. \& Hider, R. C. (1988) Blood, in the press

Stünzi, H., Perrin, D. D., Teitei, T. \& Harris, R. L. N. (1979) Aust. J. Chem. 32, 21-30

Stünzi, H., Harris, R. L. N., Perrin, D. D. \& Teitei, T. (1980) Aust. J. Chem. 33, 2207-2220

Toussaint, O. \& Lerch, K. (1987) Biochemistry 26, 8567-8571

Wilcox, D. E., Porras, A. G., Hwang, Y. T., Lerch, K., Winkler, M. E. \& Solomon, E. I. (1985) J. Am. Chem. Soc. 107, 4015-4018 